\title{
Harnessing the medicinal properties of Cussonia barteri Seem. (Araliaceae) in drug development. A review
}

\author{
IGHODARO IGBE*, OSAZE EDOSUYI, AGBONLAHOR OKHUAROBO
}

\author{
Department of Pharmacology and Toxicology \\ Faculty of Pharmacy \\ University of Benin \\ Benin City \\ Nigeria \\ * corresponding author: igbe.ighodaro@uniben.edu
}

\section{Summary}

Cussonia barteri Seem (Araliaceae) is a deciduous tree growing in savannah of Africa. Ethnomedicinally, it is used in Africa as an analgesic, anti-malarial, anti-inflammatory, anti-anaemic, anti-diarhoea, anti-poison, ani-pyschotic and anti-epileptic agent. This review provides a brief summary on the phytochemical screenings, ethnomedicinal and pharmacological applications of various parts of $C$. barteri. Leaves, stem bark and seed of $C$. barteri have been shown to be rich in saponins, flavonoids, phenols, sugars and alkaloids. Some of these constituents have been isolated and elucidated from C. barteri. Several compounds isolated from plant include triterpenes, saponins, polyenyne and quinic esters. Phytochemical constituents are also partly responsible for biological activities of $C$. barteri. Extracts and components isolated from the plant have demonstrated neuropharmacological, anti-larvicidal, anti-microbial, anti-inflammatory and antioxidant activities. Overall, the insights provided by this review reinforce the potential of $C$. barteri for drug development and create the need for further scientific probe of constituents of the plant with the aim of developing novel drug candidates.

Key words: Cussonia barteri, isolated compounds, phytochemical constituents, ethnomedicine

Słowa kluczowe: Cussonia barteri, wyizolowane związi, składniki fitochemiczne, medycyna ludowa

\section{INTRODUCTION}

Medicinal plants are sources of alternative therapies for many diseases both in developing and developed nations [1-3]. This increasing use of medicinal plants can be due to the availability, affordability, and traditional application of medicinal plants [4, 5]. As a consequence of this widespread usage, medicinal plants have gained relevant recognition from researchers, regulatory authorities and governments, leading to continuous, dynamic and broadbased research in order to evaluate them for efficacy, 
appropriate dosage, safety and scientific approval of their ethnomedicinal usefulness [6-10]. There is a widespread scientific evidence concerning biological activity of medicinal plants and compounds isolated from these plants and this immensely contributed both to use of medicinal plants formulations in therapy and in search for new drug leading the process of drug development [11-13].

The genus Cussonia has been traditionally used to manage different conditions and in production of farm tools in Africa [14]. In African traditional medicine, the uses of Cussonia and related species have been documented and reported to possess analgesic [15], anti-malarial [16], anti-inflammatory [17], anti-anaemic [18], anti-diarrhoea [19], wound healing [20], anti-poison [21], effects against mastitis, mental disorders, sexually transmitted diseases [22] and as an anti-epileptic [16]. There are about 2140 Cussonia species around African countries including Madagascar, Ghana, Senegal, Ivory Coast, Mali, Nigeria, Guinea, Liberia and Cameroon [23-25]. These species have been documented for their ethnomedicinal uses and investigations have been carried out on these plants and its isolated compounds [16, $24,26]$. Prominent among these species for distribution and ethnomedicinal uses is C. barteri.

\section{CUSSONIA BARTERI}

C. barteri Seem (Araliaceae) is a dicotyledonous, medium-sized deciduous tree, which grows up to $10-13 \mathrm{~m}$ in height. (fig. 1). It can be found growing in tropical and subtropical regions of Sub-Saharan Africa, Yemen and has a convoluted trunk and very compact, hard bark [26]. The plant has digitate leaves (5-8 ovate-elliptic leaflets); with small greenish-white flowers contained in clusters of narrow spikes up to $50 \mathrm{~cm}$ long [27]. Fruits are fleshy and turn purple to white on maturation [28]. Seasonal variations affect the shape of the plant especially in dry season where it undergoes complete defoliation. The defoliated tree resembles a 'cut off limb', earning it the name 'stump of an amputated limb' in Mali and Volta, 'leper's hand' in Hausa, Northern Nigeria [29]. The plant is also known as 'Ako-sigo' in Yoruba, 'Tuwongiwa' in Hausa, 'Bolo Koro' in Senegal and 'Kokobidua' in Ghana [30]. The seeds are also called 'jansa' seeds (Cameroun), 'Ugbaokwe' (Igbo), 'Takandagiwa' (Hausa), 'Bumarlahi' (Fulani) and 'Shigo' (Yoruba) in Nigeria [31]. The leaves, stem and root of C. barteri have been used in different African cultures in a variety of ailments.
Bearing in mind the promise C. barteri holds for drug development, the need to provide a literature update guide that will incite and guide further research on the plant, with the aim of developing novel medicines, has become imperative. Thus, this review focuses on the ethnomedicinal, phytochemical and pharmacological properties of C. barteri.

\section{ETHNOMEDICINAL USES}

C. barteri has found different applications in ethnomedicine. The plant and its macerated stem bark are used as a purgative, an aphrodisiac and as external lotion in Mali [32]. The seeds are used as additive in

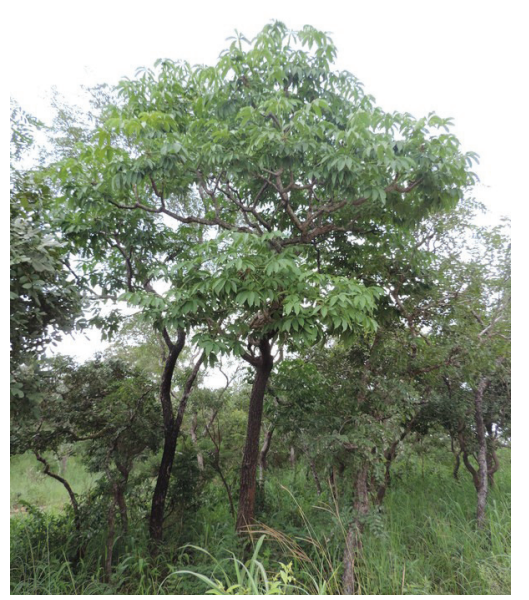

Figure 1.

Cussonia barteri in its natural habitat

soup because of its pleasant aroma and sweet taste [31]. In Nigeria and Ghana, decoctions of the root and stem bark are used for menorrhagia, rheumatism, as an emetic, as a purgative agent, poison antidote and occasionally in cases of epilepsy [33, 34]. Decoction of the root bark is used for gonococci infections in Cameroun and Tanganyika [35, 36]. The powdered stem bark is applied to leprous sores, boiled leaves are used for conjunctivitis, while the young plants are used for diarrhea in Ivory Coast and Volta [36, 37]. The fresh twigs are used to perform magical rites for oedema, paralysis and sleeping disorders [20].

\section{PHYTOCHEMISTRY}

Phytochemical constituents of various parts of the plant have been clarified by various studies (tab. 1). Early reports on the phytochemistry showed that the plant possessed constituents like oleanolic acid, sugars 
Table 1.

Isolated compounds from Cussonia barteri

\begin{tabular}{lccc}
\hline \multicolumn{1}{c}{ Compound } & Type & Plant part & References \\
\hline 1-O-Chlorogenoylchlorgenic acid & Quinic ester & Leaves & {$[22]$} \\
\hline 1-O- Chlorogenoylneochlorogenic acid & Quinic ester & Leaves & {$[22]$} \\
\hline C18-Polyacetylene, (+)-9(Z),17-octadecadiene-12,14-diyne-1,11,16-triol & Polyenyne & Leaves & {$[43]$} \\
\hline Cussonosides A and Cussonosides B & Triterpenes saponins & Stem bark & {$[23]$} \\
\hline
\end{tabular}

(glucose, L-rhamnose, L-arabinose and o-xylose) and hederagenin as aglucones [38]. The ethanol extract of leaves contains flavonoids, saponins, steroids, tannins, glycosides and carbohydrates [39]. Preliminary screening of $\mathrm{n}$-hexane extract of seeds and seed marc reported the presence of flavonoids, tannins, and glycosides and alkaloids. Quantitative phytochemical screening using the method of Harbone (1992) [40] was carried out on the powdered seed, the results revealed the amount of tannins $(720 \mathrm{mg} / \mathrm{ml})$, glycosides $(121.4 \mathrm{mg} / \mathrm{ml})$, saponins (4.4\%), alkaloids (2.4\%) and flavonoids (2.6\%). The seed was reported to contain oil (27.8\% yield) with a composition of stearic acid (1.3\%), linolenic acid and myristic acid (1\%) [31]. Nwokonkwo' (2013) study [31] demonstrated that seed oil contains high iodine (119.5\%) content and low acid values (1.4\%) and stated the seed oil's comparative advantage over commercially available oils. Low amounts of glycosides, phenols, triterpenes, sterols, saponins, alkaloids, flavonoids, tannins have been reported to be present in the methanol, hydromethanol, aqueous and hydrolysed $(1.2 \mathrm{~N} \mathrm{HCl} /$ methanol $)$ extracts of stem bark [41]. The hydrolysed extract was found to contain high amounts of glycosides, phenols, triterpenes, sterols, saponins, alkaloids, flavonoids and tannins constituents [41]. C. barteri contains constituents called polyacetylenes that have been documented to be highly toxic towards fungi, bacteria, and mammalian cells, and to display neurotoxic, anti-inflammatory and anti-platelet-aggregatory effects as well as for allergic skin reactions [42]. Methanol extract of leaves have been shown to possess rutin, different categories of quinic esters and saponins. Some of quinic esters and saponins have been isolated and elucidated. The isolated quinic esters include 1'-O-chlorogenoylchlorogenic acid and 1'-Ochlorogenoylneochlorogenic acid (fig. 2) while the isolated triterpene saponins from the methanol stem bark extract include cussonosides A and B (fig. 3) [22, 23]. The compound, C18-polyacetylene, (+)-9(Z),17octadecadiene-12,14-diyne-1,11,16-triol (fig. 4), has been isolated from ethyl acetate extract of $C$. barteri leaves [43].

\section{SOME ISOLATED COMPOUNDS AND THEIR BIOLOGICAL ACTIVITIES}

The methanol leaf extract of C. barteri accounts for some of its isolated compounds. The isolated quinic esters includes 1-O-chlorogenoylchlorgenic acid, 1-O- chlorogenoylneochlorogenic acid and rutin (fig. 2). The structures of these isolates were determined using $1 \mathrm{H}$ - and 13C-NMR spectra [22]. Papajewski et al. [22] evaluated the isolated quinic esters, saponins and rutin for anti-inflammatory activity by testing against 5-lipoxygenase and cyclooxygenase-1 inhibition and for antibacterial, antifungal and haemolytic effects; the compounds produced no effect at the studied test doses. Activity guided isolation from the ethyl acetate leaf extract has also led to the elucidation of a polyenyne; C18-polyacetylene, (+)- $9(\mathrm{Z}), 17$-octadecadiene-12,14-diyne-1,11,16-triol [43]. The polyenyne isolate, C18-polyacetylene (+)-9(Z), 17-octadecadiene-12,14-diyne-1,11,16-triol (fig. 4), possesses antibacterial activity against $B$. subtilis and Pseudomonas flourescens at $0.01 \mu \mathrm{g}$ and $2.56 \mu \mathrm{g}$, respectively, antifungal activity against Cladosporium cucumerinium at $0.16 \mu \mathrm{g}$, molluscicidal effect on Biomphalaria glabrata and haemolytic activitiy at $0.32 \mu \mathrm{g}$ against pig's blood [43]. Papajewski and his colleagues [43] also elucidated the compounds using nuclear magnetic resonance (NMR), mass spectrophotometry, infrared (IR), and ultraviolet (UV) spectroscopy. Triterpenes saponins (cussonosides A and cussonosides B) (fig. 3) have been isolated from stem bark. In this study [23], oral administration of $10 \mathrm{mg} / \mathrm{kg}$ crude extract and $1 \mathrm{mg} / \mathrm{kg}$ cussonoside A to male Swiss albino mice (25-30 g) was performed. Thirty minutes after the administration, the mice were monitored in an activity cage at graded time intervals. The crude extract was active at $10 \mathrm{mg} / \mathrm{kg}$ while cussonoside alone demonstrated sedative activity at a low dose of $1 \mathrm{mg} / \mathrm{kg}$ by decreasing motility in mice [44]. These effects were time-dependent and increased with time [23]. There was lack of activity against Biomphalaria glabrata for the crude extract and cussonoside A at $200 \mathrm{ppm}$ and $50 \mathrm{ppm}$, respectively[45]. 


\section{PHARMACOLOGY}

Anti-convulsant, toxicological evaluation, behavioural effects, antibacterial, molluscidal, antifungal, sedative, hemolytic effects are some of the pharmacological activities that have been investigated (tab. 2).

\section{Toxicological evaluations}

Yakubu [39] demonstrated the acute and subacute toxicities of ethanol leaf extract in Swiss albino mice and Wistar rats. Using the method of Lorke [46], Yakubu reported the $\mathrm{LD}_{50}$ after i.p. administration of ethanol extract to be $2154.1 \mathrm{mg} / \mathrm{kg}$ in mice; however, the extract had $\mathrm{LD}_{50}$ higher than $5000 \mathrm{mg} / \mathrm{kg}$ when administered orally. The extract was thus safe at oral doses but mortalities higher than $2154.1 \mathrm{mg} / \mathrm{kg}$ on intra-peritoneal administration were recorded. The repeated 28-day administration at doses of 100,200 and $400 \mathrm{mg} / \mathrm{kg}$ of ethanol leaf extract had no significant effect $(p<0.05)$ on the animal body weights, however, there was a significant increase in the organ weight index of the brain, liver and heart at 200 and $400 \mathrm{mg} / \mathrm{kg}$. Haematological, biochemical, lipid parameters were not significantly different $(p>0.05)$ from the control group after 28 days. Photomicrographs of heart showed no gross architectural abnormalities at all doses of extract. The extract had a dose-dependent effect on the histopathology of the kidney, liver and lungs, while $100 \mathrm{mg} / \mathrm{kg}$ caused no abnormalities, 200 and $400 \mathrm{mg} / \mathrm{kg}$ produced hyperplasia and congestion with hepatic and tubular necrosis [39]. USA).

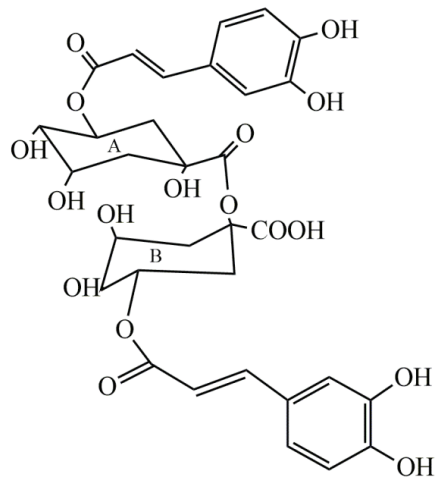

l'-O-Chlorogenoylchlorogenic<smiles>O=C(/C=C/c1ccc(O)cc1)OC1C(O)CC2(C(=O)O)CC(C(O)C(O)C2O)C1OC(=O)/C=C/c1ccc(O)cc1</smiles>

1'-O-Chlorogenoylneochlorogenic
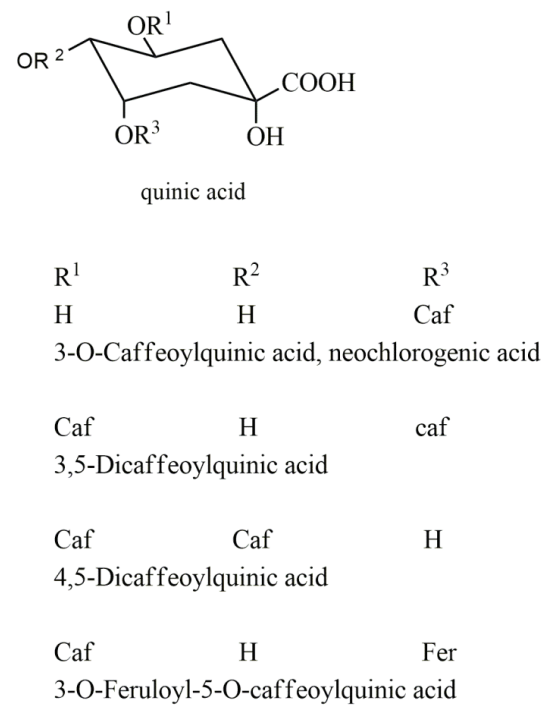

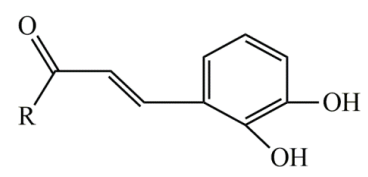

5-O-Caffeoylquinic acid, chlorogenic acid<smiles>[R]C(=O)/C=C/c1cccc(O)c1OC</smiles>

5-O-Feruloylquinic acid

Figure 2.

Isolated quinic acid esters from the leaves of C. barteri. 


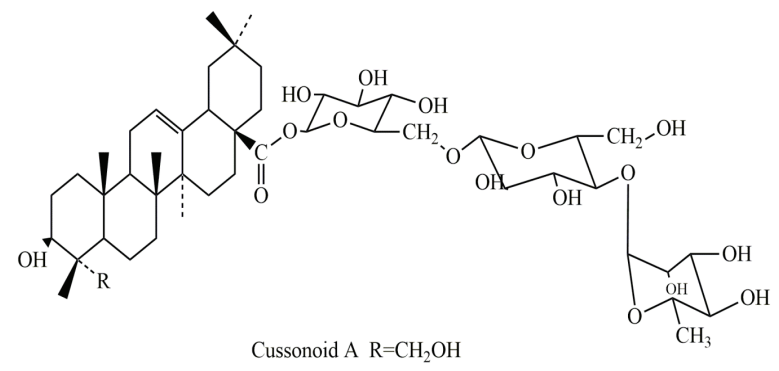

Cussonoid $\mathrm{B} \quad \mathrm{R}=\mathrm{CH}_{3}$

Figure 3.

Isolated triterpene saponins (Cussonoid A and B) from the stem bark of Cussonia barteri

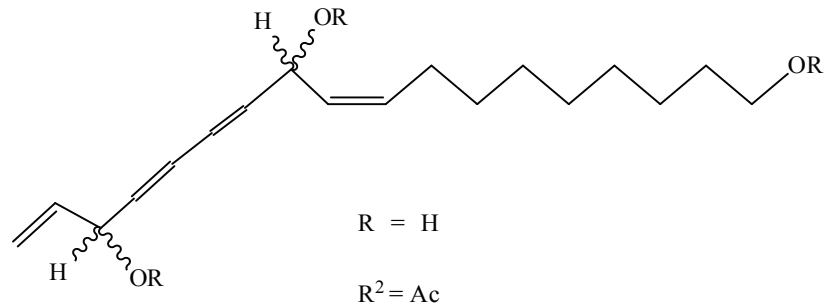

$\mathrm{R}=$ 17-octadecadiene-12,14-diyne-1,11,16-triol

$\mathrm{R}^{2}=17$-octadecadiene-12,14-diyne-1,11,16-

trioltriacetate

Figure 4.

Isolated polyenyne from the leaves of Cussonia barteri

Table 2.

Pharmacological activity of extracts and isolated compounds from Cussonia barteri

\begin{tabular}{|c|c|c|}
\hline Type of extract & Pharmacological activity & References \\
\hline Methanol and ethylacetate extract of leaves & $\begin{array}{l}\text { Bacteriostatic against } \\
\text { Bacillus subtilis } \\
\text { and Pseudomonas } \\
\text { fluorescens }\end{array}$ & {$[22,74]$} \\
\hline Ethanol leaf extract & $\begin{array}{l}\text { Anti-convulsant } \\
\text { activity against PTZ } \\
\text { and strychnine induced } \\
\text { convulsions }\end{array}$ & {$[49,51]$} \\
\hline Ethanol extract of the leaves & Sedative effect & {$[56,60]$} \\
\hline Dichlomethane, methanol, aqueous and hydromethanol root extract & $\begin{array}{l}\text { Larvicidal activity } \\
\text { against the larvae } \\
\text { of Aedes aegypti, } \\
\text { Anopheles gambiae and } \\
\text { Culex quinquefascia }\end{array}$ & [67] \\
\hline Dichlomethane, methanol and aqueous root extract, Cussonosides A and B & $\begin{array}{l}\text { Molluscidal effect } \\
\text { against Biomphalaria } \\
\text { pfeifferi and Bulinus } \\
\text { truncates snail }\end{array}$ & {$[23,32]$} \\
\hline Dichloromethanol and methanol root extract & $\begin{array}{l}\text { Anti-fungal activity } \\
\text { against Cladosporium } \\
\text { cucumerinum and } \\
\text { Candida albicans }\end{array}$ & {$[70,71]$} \\
\hline Methanol leaf extract and butanol stem bark extract & Hemolytic activity & {$[22,23]$} \\
\hline
\end{tabular}




\section{Antibacterial screening}

Bioautographic thin layer chromatography (TLC) assays were used to assess methanol and ethyl acetate extracts for activity against Bacillus subtilis and Pseudomonas fluorescens at experimental concentrations of $50 \mu \mathrm{g}$ and $250 \mu \mathrm{g}$, respectively. The activity against Bacillus subtilis and Pseudomonas fluorescens was indicated as inhibition zones or spots at 10 and $30 \mu \mathrm{g}$, respectively, on the TLC plates. However, microdilution studies revealed that the results were false positive $[22,47]$.

\section{Anticonvulsant studies}

The ethnomedicinal use of C. barteri in mental disorders led to evaluation for anticonvulsant actitvity by Yakubu [39]. Mice and fifty (50) day old white cockerels were used for this study. The extract was evaluated using maximum electroshock (MES) [48], petenelenetratrazol (PTZ) [49], picrotoxin [50], strychnine [51], aminophylline [52], isoniazid induced convulsions [53]. All doses of the extract lengthened the recovery time but did not protect the chicks against MES-induced convulsions. There was $83.3 \%$ protection at $400 \mathrm{mg} / \mathrm{kg}$ in PTZ induced convulsions, while the 100 and $200 \mathrm{mg} / \mathrm{kg}$ gave $33.3 \%$ protection. The same precedence was observed in strychnine-induced seizures, where the extract produced $50 \%$ protection at highest dose, however, the $200 \mathrm{mg} / \mathrm{kg}$ gave $83.3 \%$ protection against mortality. The extract had no effect against aminophylline, isoniazid and picrotoxininduced seizures. The extract was thus suggested to possess anticonvulsant activity in PTZ and strychnineinduced convulsions. The study concluded that the extract may not possess activity against generalized seizures and there may interaction with GABAergic transmission [54]. Flavonoids were suggested to play a role in anti-convulsant effect of the extract [55].

\section{Neurobehavioral evaluations}

Behavioral studies on the ethanol leaf extract [39] were performed using the diazepam-induced sleeping time [56], hole board test [57], mouse beam walking assay [58] and open field test [59] in experimental animals. The onset and duration of diazepam-induced sleeping time was significantly $(p<0.05)$ increased by 200 and $400 \mathrm{mg} / \mathrm{kg}$. The extract also significantly $(p<0.05) \mathrm{de}-$ creased head dips at 200 and $400 \mathrm{mg} / \mathrm{kg}$, suggesting a sedative effect and reduction in exploratory behavior
[60]. In the mouse beam walking test, there was significant increase in foot slips at $400 \mathrm{mg} / \mathrm{kg}$, but there was no significant effect on total time taken to complete the test. In the open field study, the number of rearing movements, number of total square and central square crossed and the time spent in enclosed corners were not significantly ( $p>0.05)$ affected by all doses of the extract. The study suggested the extract possessed sedative activity but lacked anxiolytic effect [61]. These sedative effects were attributed to flavonoids present in the plant. In another study by Dubois et al. [23], sedative effects were reported for $10 \mathrm{mg} / \mathrm{kg}$ stem bark extract and $1 \mathrm{mg} / \mathrm{kg}$ isolated cussonoids, corroborating claims by Yakubu and his colleagues [39]. Dubois et al. [23] posited that the sedative effect may be due to the presence of saponins.

\section{Antioxidant study}

The powdered stem bark of four medicinal plants, including $C$. barteri were extracted with water, methanol, hydroethanol and hydrolysed mixture (1.2N HCL/methanol) [41]. The antioxidant potential of each extract was assayed with 1,1-diphenyl-2-picrylhydrazyl (DPPH) [62], reducing property(FRAP) [63] and Folin-Ciocalteu methods [64]. The study revealed that the aqueous and hydroethanol extracts gave the highest antioxidant effect in all assays. All extracts of $C$. barteri showed no significant $(p>0.05)$ DPPH free radical scavenging activity. The hydrolysed extract demonstrated high catechin mg equivalent $(>500 \mathrm{mg} / \mathrm{g}$ ) in the FolinCiocalteu assay and a significant ferric reducing power ( $>80 \mathrm{mg} / \mathrm{g}$ catechin equivalent) in the FRAP assay. The study concluded that the hydrolysed extract had the highest antioxidant effect, although the antioxidant effect of $C$. barteri was not comparable to other studied plants ( $H$. madagascariensis and $A$. pterocarpoides).The study predicated the high activity of the aqueous extract to hydrolysis, which resulted in the release of bound anti-oxidant substances such as phenols [65]. In another study by Diallo et al. [32], the dichloromethanol, methanol and ethanol root bark extracts were investigated for free radical scavenging activity using thin layer chromatography (TLC). Extracts at $100 \mu \mathrm{g}$ were applied on silica gel 60 F254 plates. After elution in suitable solvent systems, carotene $\left(0.5 \mathrm{mg} / \mathrm{ml}\right.$ in $\left.\mathrm{CHCl}_{3}\right)$ was sprayed on the plates and later exposed to UV light $(254 \mathrm{~nm})$. The free radical activity was measured by spraying 2,2-diphenyl-1-picrylhydrazyl (DPPH) $(2 \mathrm{mg} / \mathrm{ml}$ in $\mathrm{MeOH})$ on the chromatogram [66]. 
Active compounds were recorded as clear spots in contrast to a purple background. The methanol extract of C. barteri showed high antioxidant and negligible DPPH radical scavenging activity.

\section{Antilarvicidal effects}

Investigations by Diallo et al. [32] on the dichloromethane, methanol, aqueous and hydromethanol extracts of the root of $C$. barteri on in-vitro larvicidal activity revealed interesting results. Larvae of Aedesaegypti, Anopheles gambiae and Culex quinquefascia were placed in $500 \mathrm{mg} / \mathrm{ml}$ solution of C. barteri extracts, the larvae were monitored for mortality after 24 hours [67]. Activity was measured by $100 \%$ kill after 24 hours. All extracts of $C$. barteri were active against all three organisms; after 1 hour of exposure to the dichloromethane, respective percentage killswere $65 \%$, 90\% and 40\% in Culex, Anopheles and Aedes larvae. Molluscidal studies were carried out on Biomphalaria pfeifferi and Bulinus truncates snails (respective hosts of Schistosoma haematobium and Schistosoma mansoni). The snails were placed in $400 \mathrm{mg} / \mathrm{ml}$ concentration of C. barteri extracts; the test was repeated five times using $150 \mathrm{ml}$ of distilled water [68]. The snails were subsequently transferred from the test solutions to distilled water and mortality was demonstrated after 24 hours. Dilutions were carried out to determine the minimum concentration of kill. The dichloromethanol, methanol and aqueous extracts of $C$. barteri recorded high molluscidal activity at $100 \mathrm{ppm}$ [69]. Diallo et al.[32] attributed the mollusical activity to the presence triterpene saponins (cussonosides $\mathrm{A}$ and $\mathrm{B}$ ), isolated from C. barteri [23]. A separate report by Papajewski [22] showed that the methanol extract lacked molluscidal activity against Biomphalaria glabrata.

\section{Antifungal studies}

Thin-layer chromatography autography study [70] and agar overlay methods [71] were used to evaluate the antifungal effect. In this study by Diallo[32], $100 \mu g$ of each C. barteri root extract were put on aluminiumbacked silica gel plates. The plates were developed with the appropriate solvent system and afterelution; the chromatograms were dried and sprayed with a conidial suspension of Cladosporium cucumerinum. Zones of inhibition were recorded after 3 days at normal room temperature. In the agar overlay test, prepared innoculums of Candida albicans in yeast in malt agar was spread over the TLC plate. The plates were incubated overnight at $30^{\circ} \mathrm{C}$ and then sprayed with the indicator: methylthiazolyltetrazolium chloride (MTT), clear spots against a purple-coloured background was positive for activity. Only the dichloromethanol (DCM) and methanol root extract of $C$. barteri showed activity against Cladosporium cucumerinum and Candida albicans. This contradicts reports from an earlier study by Papajewski [22] which demonstrated a lack of antifungal activity of the $50 \mu \mathrm{g}$ and $250 \mu \mathrm{g}$ methanol leaf extract against Cladosporium cucumerinumin bioautographic TLC studies [71].

\section{Haemolytic effect}

The hemolytic effect of the methanol leaf extract was evaluated using thin layer chromatography (TLC) bioautography [22]. Fresh pig blood buffered with citrate buffer was sprayed on TLC plates embedded with the methanol leaf extract of C. barteri; zones of agglutination were observed and recorded [22]. Agglutination zones were observed at $10 \mu \mathrm{g}$, signifying hemolytic activity. Hemolytic activity of the butanol stem bark extract was also reported by Dubois et al. [23].

\section{RESEARCH ON C. BARTERI: OVERVIEW OF PAST AND OUTLOOK ON THE FUTURE}

Our research revealed that roots, stem bark, seeds, leaves and young whole plant of C. barteri are relevant in ethnomedicinal practice in parts of Africa. Therefore, it is not surprising that the these parts of the plant have been used in pharmacological evaluation and phytochemical screening of $C$. barteri. However, it will also be worthwhile to perform the pharmacological and phytochemical screening of other aerial parts such as the flowers and fruits, especially as studies have shown that bioactive components of plants can be present in all parts [72-74]. Despite rich phytochemical components of seeds, and documented activities of the root bark, data on characterization and isolation are currently unavailable. It is therefore imperative to isolate and characterize pure compounds from extracts of parts of the plant. Similarly, bearing in mind that only pure isolated compounds are appropriate as lead compounds for drug design, it is important that the pharmacological screening aimed at developing new drug molecules from the plant shift away from crude extracts and fractions to pure isolated compounds. Some of medical conditions for which the plant is efficacious in both ethnomedicinal practice and pharmacological 
evaluation in the laboratory as revealed by this review still have unmet needs in terms of treatment outcome. This makes C. barteri worthy of optimal exploitation in the search of better therapeutic options to address the unmet needs in the treatment of these medical conditions. Also, some preliminary neurobehavioral studies suggest that the plant has some psycho-activity [56-58]. This understanding therefore warrants a drug design approach that will minimize the central nervous system-related side-effects during drug development. Furthermore, the mortalities observed in the toxicological studies presented following intraperitoneal route of administration of extract of the plant were not observed with the oral route. This suggests that the plant extract is safer when administered through the oral route. Hence, the apparent safety of the plant parts in ethnomedicinal practice is therefore not surprising, given that the oral route is the route of administration in ethnomedicinal use of the plant. Additionally, there is a need for chronic toxicity studies of the extracts and pure isolates from the plant in order to put the toxicity profile in proper perspective, more so, as parts of the plant have been found to be effective in chronic condition such as epilepsy both in ethnomedicine and preliminary pharmacological investigations [33, 34, 49, 50]. More research efforts should also be directed at exploring it potential as a food additive given that it is used in soups due to the taste and aroma its impacts on soups. Similarly, the physico-chemical properties of the seeds should also be extensively explored with a view to developing food and pharmaceutical adjuvant from the plant [31].

\section{CONCLUSIONS}

This review highlighted evidences and overview on the state of knowledge as well as future directions on research on C. barteri. As a consequence, it pointed for further investigation of the potentials of $C$. barteri for drug development using constituents of the plant for possible development of lead molecules that will help find better therapeutic options for several diseases. Thus, it is our sincere hope that this review will serve as useful guide in application the medicinal properties of $C$. barteri for the purpose of drug development.

Ethical approval: The conducted research is not related to either human or animal use.

Conflict of interest: Authors declare no conflict of interest.

\section{REFERENCES}

1. Esther AE. A review of the role of medicinal plants in traditional african medicine. Int J Ayurvedic Herb Med 2016; 1(6);2139-2144. doi: http://dx.doi. org/10.18535/ijahm

2. Sofowora A. Medicinal plants and traditional medicine in Africa. J Ethnopharmacol 1982; 10(3):332-333. doi: http://dx.doi.org/10.1016/03788741(84)90026-6

3. McGaw L, Jäger A, Van Staden J. Antibacterial, anthelmintic and anti-amoebic activity in South African medicinal plants. J Ethnopharmacol 2000;72(2):247-263. doi: http://doi.org/10.1016/ S0378-8741(00)00269-5

4. Pal SSK, Shukla Y. Herbal Medicine : Current status and the future. Asian Pac J Cancer Prev 2003; 4(80):281-288.

5. Farnsworth N, Akerele O, Bingel A. Medicinal plants in therapy; Bulletin of the World Health Organisation 1985; 63 (6):965-981.

6. Igbe I, Edosuyi O. Toxicity profile of aqueous extract of Cassia alata flower in Wistar rats. J Pharm Biores 2016; 13(2):92-102. doi: http://dx.doi. org/10.4314/jpb.v13i2.5

7. Nunes X, Silva FS, Almeida J, Delima JT, Barbosa F. Biological oxidations and antioxidant activity of natural products. In: Phytochemicals as nutraceuticals - global approaches to their role in nutrition and health. Venketeshwer Rao (Ed.). 2012. Available in :http://www.intechopen.com/books

8. Folashade O, Omoregie O, Ochogu P. Standardization of herbal medicines. A review. Int J Biodivers 2012; 4(3):101-112. doi: http://dx.doi.org/10.5897/ IJBC11.163

9. Tilburt J, Kaptchuk TJ. Herbal medicine research and global health: an ethical analysis. Bull World Health Organ 2008; 86(8):577-656. doi: http:// dx.doi.org/10.1590/S0042-96862008000800011

10. Falodun A. Harnessing the significance of natural products for diseases and beyond. Trop J Nat Prod Res 2017; 1(1):1. doi: http://doi.org/10.26538/tjn$\mathrm{pr} / \mathrm{vli1} .1$ 
11. Okorondu MMO, Adeleye SA, Okorondu AS. Review on medicinal plants. Nig J Microbiol 2015; 29(2):3167-3183.

12. Aggarwal BB, Deb L, Prasad S. Curcumin differs from tetrahydrocurcumin for molecular targets, signaling pathways and cellular responses. Molecules 2015; 20(1):38-45. doi: http://dx.doi. org/10.3390/molecules20010185

13. Carlo DG, Mascolo N, Lzzo AA, Capasso F. Flavonoids: old and new aspects of a class of natural therapeutic drugs. Life Sci 1999; 4(65):337-353. doi: http://doi.org/10.1016/S0024-3205(99)00120-4

14. Mensah AY, Mireku EA, Mensah MLK, Amponsah IK. Some neurological effects of the ethanolic stem bark extract of Cussonia bancoensis Aubrev \& Pellgr (Araliaceae). 2014. J Pharmacog Phytochem 2014; 2(60):101-106.

15. Shin K, Kim R, Azefack T, David L, Luc S. Invitro anti-inflammatory activity of 23-hydroxyursolic acid isolated from Cussonia bancoensis in murine macrophage RAW 264.7 cells. Planta Med 2004; 70(9):803-807. doi: http://doi. org/10.1055/s-2004-827226

16. De Villiers BJ, Van Vuuren SF, Van Zyl LR, Van Wyk BE. Antimicrobial and antimalarial activity of Cussonia species (Araliaceae). J Ethnopharmacol 2010; 129(2):189-196. doi: http://doi. org/10.1016/j.jep.2010.02.014

17. Iwu M. Modalities of drug administration handbook of African medicinal plants. CRC-Press INC, Florida 1993:309-330.

18. Konadu K. Indigenous medicine and knowledge in African society. New York: Routledge, Psychology Press 2007:4.

19. Amusan O, Dlamini P, Msonthi J. Some herbal remedies from Manzini region of Swaziland. J Ethnopharmacol 2001; 79(2002):109-112. doi: http://doi.org/10.1016/S0378-8741(01)00381-6

20. Hutchings A. A survey and analysis of traditional medicinal plants as used by the Zulu; Xhosa and Sotho. Bothalia 1989; 19(1):112-123. doi: http:// doi.org/ 10.4102/abc.v19i1.947

21. Lovett J, Ruffo C, Gereau R, Taplin J. Field guide to the moist forest trees of Tanzania. The Society for Environmental Exploration, UK and the University of Dar es Salaam, Tanzania 2006.

22. Papajewski S, Volger B, Conrad J, Klaber I, Roos $\mathrm{G}$, Walter CU, et al. Isolation from Cussonia barteri of 1'-O-chlorogenoylchlorogenic acid and 1'-chlorogenoylneochlorogenic acid, a new type of quinic acid esters. Planta Med 2001; 67(8):732-736. doi: http://doi.org/10.1055/s-2001-18338

23. Dubois $\mathrm{M}$, Wagner $\mathrm{H}$. Cussonosides $\mathrm{A}$ and $\mathrm{B}$, two triterpene-saponins from Cussonia barteri. Planta Med 1986; 52(2):80-83. doi: http://doi. org/10.1055/s-2007-969084

24. Harinantenaina L, Kasai R, Yamasaki K. Cussosaponins A-E, triterpene saponins from the leaves of Cussonia racemosa, a Malagasy endemic plant. Chem Pharm Bull 2002; 50(9):1290-1293. doi: http://doi.org/10.1248/cpb.50.1290

25. Irvine FR. Woody plants of Ghana with special reference to their uses. In: Woody plants of Ghana. Oxford University Press 1961:868.

26. Burkill H. The useful plants of west tropical Africa. Kew, Royal Botanical Gardens. 2nd ed. The Whitefriars Press Limited, London, 1985.

27. Keay RNJ, Onochie CFA, Standfield DP, Nigerian trees by Federal Department of Forest Research in Nigeria. Offset Lithography of the University Press, Nigeria 1964:65-67.

28. Zanoni TA, Farjon A. World Checklist and Bibliography of Conifers. Brittonia 1999; 51:76. doi: http://doi.org/10.2307/2666560

29. Kerharo J, Bouquet A. Medicinal and toxic plants of Côte d'Ivoire-Upper Volta: study mission of the indigenous pharmacopoeia in AOF. Paris: Vigot. 1950; 297. doi: http://doi.org/www.documentation.ird.fr/hor/fdi:01281

30. Irvine F R. Plants of the Gold Coast. 1930; 6(23):45.

31. Nwokonkwo DC. Physicochemical and phytochemical studies of the constituents of the seed of Cussonia barteri (Jansa Seeds). Am J Sci Ind Res 2013; 4(4):414-419. doi: http://dx.doi.org/10.5251/ ajsir.2014.5.1.7.12 
32. Diallo A, Marston C, Terreaux Y, Toure BS, Paulsen, Hostettmann K. Screening of Malian medicinal plants for antifungal, larvicidal, molluscicidal, antioxidant and radical scavenging activities. Phytother Res 2001; 15(5):401-406. doi: http:// dx.doi.org/10.1002/ptr.738

33. Watt JM, Breyer-Brandwijk MG. The medicinal and poisonous plants of Southern and Eastern Africa. 2 nd ed. 1962:107.

34. Adeniji K, Amusan O, Dlamini P, Enow-Orock E. Traditional medicine and pharmacopoeia contribution to ethnobotanical and floristic studies in Swaziland. The Scientific, Technical and Research Commision of the Organisation of African Unity (OAU/STRC) 2000; 23(4):207.

35. Jiofack T, Fokunang C, Guedje N, Kemeuze V, Fongnzossie E, Nkongmeneck BA, et al. Ethnobotanical uses of medicinal plants of two ethnoecological regions of Cameroon. Int J Med Sci 2010; 2(3):60-79.

36. Adjanohoun JE, Aboubakar N, Dramane K. Contribution to ethnobotanical andfloristic studies in Cameroon. OAU/STRC. 1986:273.

37. Brunken ZG, Schmidt U, Dressler M, Janssen S, Thiombiano T. West African plants - a photo guide - Cussonia barteri Seem. 2008. [Online]. Available: http://www.westafricanplants.senckenberg. [Accessed: 15 Sep 2017]

38. Chazan J. Répartition des sapogénines triterpéniques dans quelques genres d'araliacées de Madagascar. Phytochemistry 1971;5(76):73-87. doi: http://doi.org/10.1016/S0031-9422(00)97204-2

39. Yakubu M. Some neuropharmacological and toxicological studies of the ethanolic leaf extract of Cussonia barteri (Arialiaceae) MSc Thesis. Ahmadu Bello University, Nigeria 2014:1-81.

40. Harbone JB. Phytochemical Methods: A guide to modern technique of plant analysis. London, Chapman and Hall Ltd. 1992:279.

41. Biapa PCN, Agbor GA, Oben JE, Ngogang JY. Phytochemical studies and antioxidant properties of four medicinal plants used in Cameroon. Afr J Trad Complement Med 2007; 4(4):495-500. doi: http://dx.doi.org/10.4314/ajtcam.v4i4.31243
42. Christensen LP, Brandt K. Bioactive polyacetylenes in food plants of the Apiaceae family: occurrence, bioactivity and analysis. J Pharm Biomed Anal 2006;41(3):683-693.

43. Papajewski S, Volger B, Conrad J, Klaber I, Roos $\mathrm{G}$, Walter CU, et al. Bioassay guided isolation of a new C18-polyacetylene, (+)-9(Z)17-octa-. Planta Med 1998; 64(10):479-481. doi: http://dx.doi. org/10.1055/s-2006-957492

44. Wagner H, Jurcic K, Schaette R. Vergleichende Untersuchungen über die sedierende Wirkung von Baldrianextrakten, Valepotriaten und ihren Abbauprodukten. Planta Med 1980; 60(2):300-382. doi: http://dx.doi.org/:10.1055/s-2008-1074930

45. Domon B, Dorsaz A, Hostettmann K. High-performance liquid chromatography of oleanane saponins. J Chromatogr A 1984; 1(315):441-446. doi: http://dx.doi.org/:10.1021/jf0482663

46. Lorke D. A new approach to practical acute toxicity testing. Arch Toxicol 1983; 54(4):275-287. doi: http://doi.org/10.1007/BF01234480

47. Vanden D, Vlirtinck A. Screening methods for antibacterial agents from higher plants. Methods in Plant Biochemistry. 4th ed, Elsevier Ltd. 1993; 10:1-297.

48. Swinyard E, Kupferberg H. Antiepileptic drugs: detection, quantification, and evaluation. Fed Proc 1985; 44(10): 2629-2633.

49. Swinyard E. General principles, experimental selection, quantification, and evaluation of anticonvulsants. Antiepileptic Drugs 1989; 85-102.

50. Kulkarni S, Mehta AK, Ticku MJ. Comparison of anticonvulsant effect of ethanol aganst NMDAkainic acid and picrotoxin-induced convulsions in rats. Life Sci 1990; 46(7):481-487. doi: http://doi. org/10.1016/0024-3205(90)90003-A

51. Porter R, Cereghino J, Gladding G. Antiepileptic drug development program.Cleve Clin Q 1984; 51(2):293-305.

52. Janusz W, Wamil A. Inhibition of aminophyllineinduced convulsions in mice by antiepileptic drugs and other agents. Eur J Pharmacol 1987; 144(3):309-315. doi: http://doi.org/10.1016/00142999(87)90383-9 
53. Kale S, Shete R, Kore K, Patil B, Bhutada R. Anticonvulsant activity of glycyrrhizic acid in mice. Int J Pharm Res \& Devel 2010; 2(10):123-128.

54. De G, Sarro G, Ferreri P, Gareri, Russo E. Comparative anticonvulsant activity of some 2,3-benzodiazepine derivatives in rodents. Pharmacol Biochem Behav 2003; 74(3):595-602. doi: http:// doi.org/10.1016/S0091-3057(02)01040-7

55. Hanrahan JR, Chebib M, Johnston GAR. Flavonoid modulation of GABAA receptors. Br J Pharmacol 2011; 163(2):234-245. doi: http://dx.doi. org/:10.1111/j.1476-5381.2011.01228.x

56. Beretz A, Haag-Berrurier M, Anton R. Choix de méthodes pharmacologiques pour létude des activités de laubépine. Plantes mèdicinales et phytotherapie. 1978; 4(4):305-314.

57. File S, Wardill A. Validity of head-dipping as a measure of exploration in a modified hole-board. J Psychopharmacol 1975; 44(3):53-59. doi: http:// doi.org/10.1007/BF00421184

58. Stanley J, Lincoln R, Brown T. The mouse beam walking assay offers improved sensitivity over the mouse rotarod in determining motor coordination deficits induced by benzodiazepines. J Psychopharmacol 2005; 19(3):221-227. doi: http://doi. org/10.1177/0269881105051524

59. Brown R, Corey S, Moore A. Differences in measures of exploration and fear in MHCcongenic C57BL/6J and B6-H-2K mice. Behav Genet 1999; 26(2):263-271. doi: http://doi. org/10.1023/A:1021694307672

60. File S, Pellow S. The effects of triazolobenzodiazepines in two animal tests of anxiety and in the holeboard. Br J Pharmacol 1985; 86(1):729-735. doi: http://dx.doi.org/:10.1111/j.1476-5381.1985. tb08952.x

61. Mechan A, Moran P, Elliott M. A single neurotoxic dose of 3,4-methylenedioxymethamphetamine (MDMA) on the subsequent long-term behaviour of rats in the plus maze and open field. J Psychopharmacol 2002; 159(6):188-195. doi: http://dx.doi. org/: 10.1007/s002130100900

62. Hatano T, Kagawa H, Yasuhara T. Two new flavonoids and other constituents in licorice root: their relative astringency and radical scavenging effects. Chem Pharm Bull 1988; 36(6):2090-2097. doi: http://doi.org/10.1248/cpb.36.2090

63. Benzie IFF, Strain JJ. The ferric reducing ability of plasma (FRAP) as a measure of antioxidant power: the FRAP assay. Anal Biochem 1996; 239(1):70-76.

64. Singleton V, Orthofer R, Lamuela-Raventós R. Analysis of total phenols and other oxidation substrates and antioxidants by means of FolinCiocalteu reagent. Methods Enzymol 1999; 31(299):152-178. doi: http://doi.org/10.1016/ S0076-6879(99)99017-1

65. Agbor G, Oben J, Ngogang J, Xinxing C, Vinson JA. Antioxidant capacity of some herbs/spices from Cameroon: a comparative study of two methods. J Agric Food Chem 2005; 53(17):6819-6824. doi: http://dx.doi.org/: 10.1021/jf050445c

66. Cuendet M, Hostettmann K, Potterat O. Iridoid glucosides with free radical scavenging properties from Fagraea blumei. Helv Chim Acta 1997; 80(4):1152-1154. doi: http://dx.doi.org/10.1002/ hlca.19970800411

67. Marston A, Maillard M, Hostettmann K. Search for antifungal, molluscicidal and larvicidal compounds from African medicinal plants. J Ethnopharmacol 1993; 38(2-3):209-214. doi: http:// dx.doi.org/10.1002/ptr.738

68. Bashir A, Sulaiman S, El Sheikh S, El Kheir Y. Molluscicidal, cercaricidal and miracidicidal activities of Acacia nilotica ssp. nilotica and adansonii. Fitoterapia 1987; 8(23):54-57.

69. World Health Organisation (1965). Molluscicide screening and evaluation. Bull World Health Organ 1965; 33(4):567-581.

70. Homans A, Fuchs A. Direct bioautography on thin-layer chromatograms as a method for detecting fungitoxic substances. J Chromatogr A 1970; 1(51):327-329. doi: http://doi.org/10.1016/S00219673(01)96877-3

71. Rahalison L, Hamburger MA. Bioautographic agar overlay method for the detection of antifungal compounds from higher plants. Phytochemical 1991;2(5):199-203. doi: http://dx.doi.org/.10.1002/ pca. 2800020503 
72. Igbe I, Ching FP, Eromon A. Anti-inflammatory activity of aqueous fruit pulp extract of Hunteria umbellata K. Schum in acute and chronic inflammation. Acta Pol Pharm 2010; 67(1):81-85.

73. Okhuarobo A, Falodun JE, Erharuyi O, Imieje V, Falodun A, Langer P. Harnessing the medicinal properties of Andrographis paniculata for diseases and beyond: a review of its phytochemis- try and pharmacology. Asian Pac J Trop 2014; 4(3):213-222. doi: http://doi.org/10.1016/S22221808(14)60509-0

74. Ijeh II, Ejike CE. Current perspectives on the medicinal potentials of Vernonia amygdalina. J Med Plants Res 2011; 5(7):1051-1061. 